\title{
هيئة التصرير
}

$$
\text { رئيس التحرير }
$$

محرر العلومم الإنسانية والعلوم الاجتماعية

$$
\text { محرر العلومم }
$$

محرر العلومم التربوية

محرر العلومم الاقتصادية والإدارية

محرر اللغة العربية وآدابـها

محرر اللغة الإنجليزية وآدابـها
أ.د. جميل خضر

$$
\text { د. سعيد عياد }
$$

د. هاشم شاهين

د. هالة راشـد اليمني

الأستاذ حسامم وهاب

د. زين العابدين العواودة

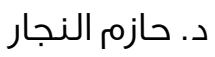

